\title{
Wojciech Gonet*
}

\section{KONSEKWENCJE NARUSZENIA UMOWNEGO PRAWA PIERWSZEŃSTWA NABYCIA UDZIAŁÓW I AKCJI}

\begin{abstract}
Streszczenie
Artykuł dotyczy skutków naruszenia umownego prawa pierwszeństwa nabycia udziałów/akcji. Ustanawiając umowne prawo pierwszeństwa udziałów/akcji, wspólnicy chcą mieć wpływ na zmiany osobowe wspólników poprzez możliwość nabycia zbywanych udziałów/akcji od podmiotów, które nie chcą być już wspólnikami. W wyniku przeprowadzonej analizy stwierdzono, że zbycie udziałów/akcji z naruszeniem prawa pierwszeństwa dotknięte jest sankcją bezskuteczności zawieszonej względem wspólników/akcjonariuszy, którym przysługuje prawo pierwszeństwa nabycia udziałów/akcji spółki kapitałowej. Nabywca udziałów/akcji z naruszeniem prawa pierwszeństwa może wykonywać prawa z udziałów/akcji, np. głosować podczas zgromadzeń wspólników/ walnych zgromadzeń akcjonariuszy.
\end{abstract}

Słowa kluczowe: akcja, spółka kapitałowa, prawo pierwszeństwa

\section{Wprowadzenie}

Podmioty zakładające spółki kapitałowe (z o.o., akcyjne) nie mogą wykluczyć zmiany składu wspólników/akcjonariuszy przez cały czas trwania spółki.

${ }^{*}$ notariusz dr hab. Wojciech Gonet prof. PW, Wydział Administracji i Nauk Społecznych Politechniki Warszawskiej, e-mail: gonetw@interia.pl 
Zmiana składu wspólników/akcjonariuszy może nastąpić z przyczyny niezależnej od wspólników (śmierć osoby fizycznej), na skutek przyczyn spowodowanych działaniem innych osób, np. upadłość wspólnika spowodowana złożeniem wniosku przez jego wierzycieli, czy też wskutek odpłatnych/niepłatnych czynności prawnych dokonanych przez samych wspólników dotyczących zbycia udziałów/akcji. Dla osób fizycznych/prawnych, którym przysługują udziały/akcje spółki kapitałowej nie jest obojętne, jaki podmiot wstąpi w prawa i obowiązki wspólnika, który zamierza zbyć przysługujące mu udziały/akcje. Dotyczy to m.in. zgodności w podejmowaniu uchwał podczas zgromadzeń wspólników/ walnych zgromadzeń, prowadzenia spraw spółki i jej reprezentowania w sytuacjach, gdy nowy wspólnik/akcjonariusz zostanie wybrany do zarządu spółki kapitałowej.

Przepis art. $182 \S 1$ k.s.h. stanowi, że zbycie udziału, jego części lub ułamkowej części udziału oraz zastawienie udziału, umowa spółki może uzależnić od zgody spółki albo w inny sposób ograniczyć. Przedmiotowym „innym ograniczeniem", o którym mowa w art. $182 \S 1$ k.s.h. in fine jest prawo pierwszeństwa nabycia udziałów sp. z o.o. przez dotychczasowych wspólników. Przepis art. 304 $\S 2$ pkt 4 k.s.h. stanowi, że statut spółki akcyjnej może zawierać postanowienia dotyczące ograniczeń zbywalności akcji pod rygorem bezskuteczności wobec spółki. Powołany przepis obowiązujący w spółkach akcyjnych oznacza, że gdy w statucie spółki brakuje postanowień dotyczących prawa pierwszeństwa nabycia przez dotychczasowych akcjonariuszy, późniejsze umowne ograniczenia zbywalności akcji zawarte pomiędzy akcjonariuszami nie powodują żadnych skutków prawnych dla spółki akcyjnej. Nabywca akcji z pominięciem umownego prawa pierwszeństwa nabycia akcji zawartego w osobnej umowie pomiędzy wspólnikami, poza statutem spółki akcyjnej, jest akcjonariuszem spółki i nie można mu odmówić wykonywania praw z akcji.

Na podstawie powołanych przepisów k.s.h. wspólnicy/akcjonariusze mogą wykreować umowne prawo pierwszeństwa nabycia udziałów/akcji w umowie/ akcie założycielskim jednoosobowej sp. z o.o. lub statucie spółki akcyjnej. Zawarcie $\mathrm{w}$ umowie/statucie spółki kapitałowej postanowień dotyczących prawa pierwszeństwa nabycia udziałów/akcji oznacza, że dotychczasowi wspólnicy mają możliwość nabycia udziałów/akcji z pierwszeństwem przed innymi osobami, w szczególności niebędącymi wspólnikami/akcjonariuszami spółki kapitałowej w przypadku, gdy dotychczasowy wspólnik/akcjonariusz zamierza zbyć (sprzedać, darować, zamienić, itp.) przysługujące mu udziały/akcje (tzw. nabycie 
pochodne $)^{1}$. Prawo pierwszeństwa nabycia może mieć również charakter pierwotny, gdy umowa/statut spółki kapitałowej wskazują, że w przypadku powstania nowych udziałów/akcji dotychczasowi wspólnicy/akcjonariusze mają pierwszeństwo ich objęcia ${ }^{2}$. Prawo pierwszeństwa jest prawem podmiotowym służącym realizacji interesu uprawnionych (wspólników, akcjonariuszy), polegającym na możliwości nabycia zbywanych udziałów/akcji z pierwszeństwem przed osobami spoza ich grona, którego korelatem jest powinność podmiotu zobowiązanego do wykonania działań zmierzających bezpośrednio do zawarcia z uprawnionym(i) umowy przenoszącej udziały/akcje, przed osobami trzecimi oraz obowiązek zaniechania wszelkich działań, które uniemożliwiałyby wykonanie prawa pierwszeństwa, w szczególności zaniechanie zbycia udziałów/akcji z naruszeniem prawa pierwszeństwa ${ }^{3}$. Opracowanie dotyczy pochodnego prawa pierwszeństwa nabycia akcji/udziałów spółki kapitałowej uregulowanego w umowie/akcie założycielskim sp. z o.o., statucie spółki akcyjnej. Zakres analizy nie dotyczy sytuacji określonej w art. 338 k.s.h., tj. ustanowienia prawa pierwszeństwa nabycia akcji inną umową, zawartą pomiędzy akcjonariuszami na okres nie dłuższy niż 10 lat. Źródłem prawa pierwszeństwa, o którym mowa w art. 338 k.s.h. jest inna umowa zawarta pomiędzy akcjonariuszami, a nie statut spółki akcyjnej. Naruszenie prawa pierwszeństwa nabycia określonego w art. 338 k.s.h. powoduje skutek wyłącznie pomiędzy stronami umowy, co wyklucza sankcję nieważności czy też bezskuteczności umowy ${ }^{4}$.

Celem artykułu jest analiza, na ile wprowadzenie w umowie/statucie spółki kapitałowej postanowień dotyczących pochodnego prawa pierwszeństwa nabycia udziałów/akcji chroni dotychczasowych wspólników przed zmianami wspólników/akcjonariuszy w spółce kapitałowej.

\section{Określenie prawa pierwszeństwa nabycia udziałów/akcji}

Przepisy k.s.h. nie zawierają regulacji wskazujących, jak określić pochodne prawa pierwszeństwa nabycia akcji/udziałów ani skutków naruszenia umownego

${ }^{1}$ M. Matuszczak, Prawo pierwszeństwa pochodnego nabycia praw udziałowych $w$ spótkach kapitałowych, Warszawa 2013, s. 18.

${ }^{2}$ Ibidem, s. 18.

${ }^{3}$ Ibidem, s. 137.

${ }^{4}$ Ibidem, s. 329. 
prawa pierwszeństwa nabycia udziałów/akcji, tzn. sytuacji, gdy wspólnik zbędzie udziały/akcje bez poinformowania zarządu spółki/wspólników o zamiarze zbycia, uniemożliwiając im wykonanie przysługującego im uprawnienia. Zwykle w umowie/akcie założycielskim sp. z o.o., statucie spółki akcyjnej zapisy określające prawo pierwszeństwa mają następującą postać:

a) wspólnikom/akcjonariuszom przysługuje prawo pierwszeństwa nabycia udziałów akcji przeznaczonych do zbycia (sprzedaży, darowizny, zamiany itp.);

b) wspólnik/akcjonariusz, chcący zbyć udziały/akcje, jest zobowiązany poinformować o tym zarząd spółki, wskazując np.: wartość zbywanych udziałów/akcji, liczbę zbywanych udziałów/akcji, podmiot zamierzający nabyć udziały/akcje;

c) zarząd informuje wspólników/akcjonariuszy lub ogłasza o możliwości skorzystania z prawa pierwszeństwa w określonym w umowie/statucie spółki terminie;

d) uprawnieni, którzy złożyli oświadczenia o zamiarze wykonania prawa pierwszeństwa, nabywają udziały/akcje zwykle proporcjonalnie do przysługujących im udziałów/akcji lub według zasady, że kto pierwszy złoży oświadczenie o zamiarze wykonania prawa pierwszeństwa, ten może nabyć cały lub część pakietu udziałów/akcji przeznaczonych do zbycia, a resztę mogą nabyć dalsi w kolejności zgłoszeń wspólnicy/akcjonariusze;

e) w przypadku niezawarcia umowy przenoszącej udziały/akcje w określonym przez umowę/akt założycielski sp. z o.o., statut spółki akcyjnej, terminie pomiędzy zbywającym a dotychczasowymi wspólnikami/akcjonariuszami lub braku zainteresowania ze strony wspólników/akcjonariuszy, nabyciem zbywanych udziałów/akcji, przedmiotowe udziały/ akcje mogą być zbyte dowolnemu podmiotowi;

f) wskazanie sankcji za naruszenie umownego prawa pierwszeństwa nabycia, np.: kar umownych, bezskuteczności z możliwością potwierdzenia czynności prawnej przenoszącej udziały/akcje przez wszystkich wspólników/akcjonariuszy.

Sankcje za naruszenie umownego prawa pierwszeństwa nabycia udziałów/ akcji mogą nie być przewidziane w umowie/akcie założycielskim sp. z o.o., statucie spółki akcyjnej. W takim przypadku, na mocy art. 2 k.s.h., należy stosować zasady dotyczące naruszenia umownych praw określone w k.c. Umowy jako czynności 
prawne mogą być bezwzględnie nieważne, wzruszalne, dotknięte bezskutecznością - wynikającą z aktu prawnego (ustawy) - względną lub zawieszoną55.

\section{Sankcje za naruszenie umownego prawa pierwszeństwa}

Zawarcie w umowie/akcie założycielskim sp. z o.o., statucie spółki akcyjnej, zapłaty kary umownej w określonej wysokości, możliwości dochodzenia roszczeń odszkodowawczych na zasadach ogólnych za naruszenie umownego prawa pierwszeństwa nabycia akcji/udziałów, nie chroni pozostałych wspólników/ akcjonariuszy przed zmianą składu osobowego spółki. Podmiot, który zamierza zbyć udziały/akcje, jeżeli jest gotowy zapłacić karę umowną, może np. darować przysługujące mu udziały/akcje z naruszeniem określonego w umowie/akcie założycielskim sp. z o.o., statucie spółki akcyjnej, umownego prawa pierwszeństwa. Dotyczy to również konsekwencji wypłaty roszczeń odszkodowawczych, przy czym pozbawienie wspólników/akcjonariuszy możliwości skorzystania z prawa pierwszeństwa oznacza odpowiedzialność za szkodę w granicach ujemnego interesu umownego ${ }^{6}$.

W wyroku SN z 11.01.2002 roku, IV CKN 1903/007 sąd stwierdził, że w umowie spółki z o.o. można wprowadzić prawo pierwszeństwa lub prawo pierwokupu udziałów na rzecz określonych podmiotów (z reguły pozostałych wspólników). Sąd przyjął, że prawo pierwszeństwa nie powoduje powstania u uprawnionych prawa podmiotowego, czym różni się od prawa pierwokupu. Prawo pierwszeństwa nie ma jednorodnego charakteru prawnego, stanowi określoną preferencję kandydatów do nabycia udziałów. Polega ono przede wszystkim na eliminacji innych podmiotów, ubiegających się o tę samą rzecz. Jego konstrukcja jurydyczna nie jest oparta na uprawnieniu, lecz na tkwiącym immanentnie w pierwszeństwie zakazie zadysponowania rzeczą w sposób je naruszający. W powołanym wyroku SN uznał, że naruszenie prawa pierwszeństwa nie wpływa na ważność dokonanej czynności.

W wyroku SN z 29.01.2004 roku, II CK 368/028 sąd stwierdził, że umowne prawo pierwokupu jest prawem podmiotowym kształtującym i nie podlega

\footnotetext{
${ }^{5}$ Ibidem, s. 245-246 i przywołana tam literatura.

${ }^{6}$ Ibidem, s. 330.

${ }^{7}$ LEX nr 53720.

${ }^{8}$ LEX nr 174175.
} 
ochronie na podstawie art. 59 k.c. (bezskuteczność względna), który z założenia służy realizacji roszczenia przysługującego osobie trzeciej względem jednej ze stron umowy. Czym innym jest prawo pierwokupu, jako prawo podmiotowe, a czym innym realizacja uprawnienia wynikającego z tego prawa. Argumentem przemawiającym przeciwko zastosowaniu konstrukcji opartej na bezskuteczności względnej do ochrony umownego prawa pierwokupu jest ocena skutków uznania bezwarunkowej sprzedaży za bezskuteczną względem uprawnionego. Konieczną przesłanką realizacji umownego prawa pierwokupu jest istnienie skutecznej i warunkowej umowy sprzedaży z osobą trzecią. Uznanie tej umowy za bezskuteczną względem uprawnionego pozbawia go koniecznego substratu do wykonania przysługującego mu prawa. Prowadzi to do wniosku, że w wypadku sporządzenia bezwarunkowej umowy sprzedaży prawo pierwokupu wygasa, a pomiędzy zobowiązanym a uprawnionym powstaje ex lege roszczenie odszkodowawcze, o którym mowa w art. 599 § 1 k.c. W literaturze przedmiotu słusznie wskazuje się, że wykazanie szkody na skutek niemożności wykonania prawa pierwokupu jest zadaniem trudno wykonalnym, a interesy osoby uprawnionej z tytułu umownego prawa pierwokupu nie są chronione9. W wyroku SN z 10.10.2008 roku II CSK 221/08 roku ${ }^{10}$ sąd orzekł, że bezwarunkowa umowa zbycia nieruchomości zawarta przez osobę zobowiązaną z umownego prawa pierwokupu z osobą trzecią może być uznana za bezskuteczną w stosunku do prawa pierwokupu (art. 59 k.c.) tylko w takim zakresie, w jakim czyni jego prawo niewykonalnym; wobec uprawnionego umowa ta powinna zostać uznana za zawartą pod warunkiem, że skorzysta on z prawa pierwokupu w przewidzianym terminie.

Powołane dwa odmienne wyroki SN dotyczące skutków naruszenia umownego prawa pierwokupu wskazują, że w orzecznictwie brakuje jednolitego stanowiska w zakresie sankcji za naruszenie umownego prawa pierwokupu, które jest innym prawem od umownego prawa pierwszeństwa nabycia. Różnica między tymi uprawnieniami polega m.in. na sposobie wykonania obu praw. W przypadku prawa pierwokupu wykonanie następuje po zawarciu zobowiązującej (warunkowej) umowy sprzedaży, pomiędzy zobowiązanym a osobą trzecią. Dopiero wtedy uprawniony może złożyć oświadczenie o wykonaniu prawa pierwokupu i nabyć rzecz/prawo. Niewykonanie prawa pierwokupu prowadzi

\footnotetext{
${ }^{9}$ R. Strzelczyk, Prawo obrotu nieruchomościami, Warszawa 2011, s. 187-188.

${ }^{10}$ Lex nr 484795.
} 
do zawarcia umowy przeniesienia własności pomiędzy zobowiązanym a osobą trzecią. Wykonanie prawa pierwszeństwa nie wymaga zawarcia żadnej umowy, a zobowiązany i uprawniony mogą ustalić jej postanowienia po złożeniu oświadczenia o skorzystaniu z prawa pierwszeństwa. Prawo pierwokupu jest uprawnieniem prawnokształtującym ${ }^{11}$, a w przypadku praw pierwszeństwa zasadniczym uprawnieniem jest roszczenie ${ }^{12}$.

Bezwzględna nieważność czynności prawnych wynika m.in. z przepisu prawa rangi ustawowej w sytuacji naruszenia norm prawa powszechnie obowiązujących. Bezwzględnej nieważności czynności prawnej nie można domniemywać. Uregulowane w umowie/akcie założycielskim sp. z o.o., statucie spółki akcyjnej, prawo pierwszeństwa nabycia udziałów/akcji ma swe źródło w umowie, a nie w ustawie. Przepisy k.s.h. i k.c. nie wskazują sankcji bezwzględnej nieważności za naruszenie prawa pierwszeństwa nabycia udziałów/akcji określonego w umowie/akcie założycielskim sp. z o.o., statucie spółki akcyjnej, wobec czego należy przyjąć, że zbycie udziałów/akcji z naruszeniem umownego prawa pierwszeństwa jest ważną czynnością prawną, co wynika również z powołanego wyroku SN z 11.01.2002 roku, IV CKN 1903/00.

Wzruszalność czynności prawnych oznacza, że czynność prawna wywołuje wszystkie określone w niej skutki prawne. Przyjęcie jako konsekwencji wzruszalności czynności prawnej zbycia udziałów/akcji z naruszeniem prawa pierwszeństwa prowadziłoby do wniosku, że zobowiązany skutecznie przeniósł na nabywcę udziały/akcje. Przesłankami wzruszenia czynności prawnych są np.: błąd, podstęp, groźba, wyzysk. Wymienione przesłanki występują dość rzadko, wobec czego nie można przyjąć ogólnej zasady, że zbycie udziałów/akcji z naruszeniem umownego prawa pierwszeństwa podlega wzruszeniu.

Do naruszenia umownego prawa pierwszeństwa nie można przyjąć bezskuteczności względnej, gdyż czynność dotknięta tą sankcją jest w pełni ważna i skuteczna wobec wszystkich osób, z wyłączeniem tej, która uzyskała konstytutywny wyrok sądu orzekający bezskuteczność względną ${ }^{13}$. Nie można także przyjąć sankcji bezskuteczności, wynikającej z aktu prawnego (ustawy), gdyż przepisy żadnej z ustaw nie wskazują na bezskuteczności ex lege zbycia udziałów/

\footnotetext{
${ }^{11}$ M. Matuszczak, Prawo pierwszeństwa..., s. 32 i przywołana literatura.

12 Ibidem, s. 32.

${ }^{13}$ Ibidem, s. 246.
} 
akcji z naruszeniem prawa pierwszeństwa ${ }^{14}$. W literaturze przedmiotu wskazuje się, że zbycie udziałów/akcji z naruszeniem prawa pierwszeństwa określonego w umowie/akcie założycielskim sp. z o.o., statucie spółki akcyjnej, dotknięte jest sankcją bezskuteczności zawieszonej, co oznacza, że umowa zbycia udziałów jest niezupełna (kulejąca) i może być potwierdzona przez wspólników/akcjonariuszy uprawnionych do prawa pierwszeństwa ${ }^{15}$. Wskazuje się również, że jest to jedyna sankcja ${ }^{16}$, jaką można zawrzeć w umowie/statucie spółki, obok kar umownych i odpowiedzialności odszkodowawczej. Bezskuteczność zawieszona oznacza, że nabywca udziałów/akcji może wyznaczyć wspólnikom/akcjonariuszom termin do potwierdzenia umowy. Gdy wspólnicy/akcjonariusze oświadczą, że nie korzystają z prawa pierwszeństwa, umowa zbycia jest w pełni skuteczna. Wspólnicy/ akcjonariusze mogą odmówić udzielenia potwierdzenia, co prowadzi do nieważności czynności zbycia udziałów/akcji z naruszeniem prawa pierwszeństwa ze skutkiem wstecznym. Taki sam skutek występuje w przypadku braku jakiejkolwiek odpowiedzi od wspólników/akcjonariuszy w terminie wyznaczonym przez nabywcę udziałów/akcji z naruszeniem prawa pierwszeństwa nabycia. Bezskuteczność zawieszona nabycia udziałów/akcji w przypadku ich nabycia z naruszeniem prawa pierwszeństwa nie oznacza niemożliwości wykonywania praw korporacyjnych oraz ujawnienia nabywcy udziałów w rejestrze przedsiębiorców krajowego rejestru sądowego. Nabywca może wykonywać prawa z udziałów/ akcji, w tym głosować podczas zgromadzenia wspólników/walnego zgromadzenia. Przyjęcie odmiennego rozwiązania mogłoby doprowadzić w niektórych przypadkach do niemożliwości zwołania zgromadzenia wspólników/walnego zgromadzenia. Dotyczy to w szczególności spółek dwuosobowych, w których umowach/statutach wprowadzono prawo pierwszeństwa nabycia udziałów/akcji. Zbywający (zobowiązany) oraz zarząd spółki może nie dysponować żadnymi wiadomościami o drugim wspólniku (uprawnionym), włącznie z pozostawaniem przez niego przy życiu i miejscem jego przebywania. Zbycie przez zobowiązanego udziałów/akcji bez zawiadomienia spółki i drugiego wspólnika skutkuje bezskutecznością zawieszoną wobec wspólnika uprawnionego. Nabywca może jednak wykonywać prawa z udziałów/akcji. Przyjęcie odmiennego rozwiązania, czyli że bezskuteczność dotyczy również spółki oznaczałoby, iż nabywca nie

\footnotetext{
${ }^{14}$ Ibidem, s. 258.

${ }^{15}$ Ibidem, s. 270.

${ }^{16}$ Ibidem, s. 272-273.
} 
może wykonać prawa z udziałów/akcji, w tym nie mógłby np. powołać/odwołać członków zarządu/rady nadzorczej, czy też podjąć uchwały o zatwierdzeniu rocznego sprawozdania finansowego.

\section{Podsumowanie}

Bezskuteczność zawieszona względem wspólników/akcjonariuszy, którym przysługuje prawo pierwszeństwa nabycia udziałów/akcji spółki kapitałowej, jest wystarczającą sankcją za naruszenie prawa pierwszeństwa nabycia udziałów/akcji określonego w umowie/akcie założycielskim sp. z o.o., statucie spółki akcyjnej. Dotyczy to także sytuacji, gdy umowa/statut spółki nie wskazują bezpośrednio przedmiotowej konsekwencji. Sankcja ta może być dodatkowo wzmocniona karami umownymi oraz odpowiedzialnością odszkodowawczą na zasadach ogólnych. Konsekwencję zbywania udziałów/akcji z naruszeniem umownego prawa pierwszeństwa, podobnie jak w przypadku umownego prawa pierwokupu, kształtuje orzecznictwo SN i sądów powszechnych, które w zakresie skutków naruszenia umownego prawa pierwokupu jest odmienne. Nie można wykluczyć, że SN w jakimś orzeczeniu uzna, iż naruszenie umownego prawa pierwszeństwa nabycia udziałów/akcji skutkuje jedynie odpowiedzialnością zobowiązanego za szkodę w granicach ujemnego interesu umownego, bez sankcji bezskuteczności zawieszonej. $\mathrm{W}$ takim przypadku ochrona wspólników/akcjonariuszy przed zmianą osobową w spółce kapitałowej poprzez wprowadzenie w umowie/statucie umownego prawa pierwszeństwa nabycia udziałów/akcji będzie iluzoryczna. Sankcja bezskuteczności zawieszonej za naruszenie umownego prawa pierwszeństwa wystarczająco chroni wspólników/akcjonariuszy przed zbyciem udziałów/akcji osobom trzecim spoza grona wspólników.

\section{Literatura}

Matuszczak M., Prawo pierwszeństwa pochodnego nabycia praw udzialowych w spótkach kapitałowych, Warszawa 2013.

Strzelczyk R., Prawo obrotu nieruchomościami, Warszawa 2011.

Wyrok SN z 11.01.2002 r., IV CKN 1903/00, Lex nr 53720.

Wyrok SN z 29.01.2004 r., II CK 368/02, Lex nr 174175.

Wyrok SN z 10.10.2008 r. II CSK 2008, Lex nr 484795. 


\title{
CONSEQUENCES OF BREACH OF CONTRACTUAL PRIORITY RIGHT OF ACQUISITION OF SHARES
}

\begin{abstract}
Summary
This article deals with the effects of breach of the contractual priority right of shares. By establishing a contractual priority shareholding, partners want to influence the shareholders' personal changes through the possibility of acquiring divested shares from entities that no longer want to be partners. As a result of the analysis, it was stated that the sale of shares in violation of the pre-emption right is affected by the penalty of ineffective suspension with respect to the shareholders who are entitled to the right of priority to purchase shares in a capital company. The purchaser of shares in violation of the pre-emption right may exercise voting rights, eg voting at shareholder meetings/ general meetings of shareholders.
\end{abstract}

Keywords: share, capital company, priority right 